\title{
Jane Franklin (1791-1875)
}

In her biography of Jane Franklin, Frances Woodward notes that one is "tempted to believe that the most interesting thing about Franklin is his choice of wives." The temptation exists because both of his wives were anything but shadowy presences next to their accomplished husband: both were intelligent, curious, and high-spirited to the point of stubbornness. The first, a London poetess, succumbed to tuberculosis after only 18 months of marriage, but even when one week from death, she encouraged her husband to leave her and proceed with his 1825 arctic overland expedition. The second, Jane, outlived her husband by many years, and her indefatigable efforts and "will to believe" led to the recovery of the only document that suggests the fate of the lost Franklin expedition. Her refusal to give up the search inspired many others, and while they searched for Franklin they laid bare large areas of the Arctic that had hitherto been terra incognita.

Jane Griffin was born on 4 December 1791, the daughter of a silk-weaver of Huguenot stock. She was educated in a Chelsea boarding school. She possessed an active intelligence and a certain "unfeminine" curiosity that took her, at the age of 17, into the hold of a prison ship stationed in the Tamar near Plymouth, as it would later take her into prisons in Van Diemen's Land and into regions where no European woman had ever before ventured.

A compulsive journal-keeper and traveller, Jane displayed a corresponding interest in reading and study. As a young woman, she drew up a formidable plan calling for daily study of the gospels and epistles, history and logic, languages, mathematics, conversation and music. The saving feature of the plan is the rueful "Alas! Alas!" written at its end.

The first "Arctic" reference in Jane's journals is a note about the Buchan/Franklin expedition of 1818. But she had not yet met John Franklin, and until her early thirties her romantic concerns were polarized between Adolphe Butini, a doctor-tobe, and Dr. Roget, future author of the Thesaurus. She was soon to be introduced to Franklin, however, as her close friend, Eleanor Porden, married him in 1823. A child was born the following year, and in the year after that, Eleanor Franklin died of tuberculosis. On 5 November 1828, Franklin married Jane Griffin.

In 1830, during the Greek struggle for independence, Franklin was stationed in the Mediterranean, and Jane accompanied him. Based in Malta, she travelled into North Africa, Spain, Greece, Syria, and Crete; she writes of fending off, undaunted, "bugs, cockroaches, ants, fleas, spiders, and rats."

In 1836, Jane followed her husband to Van Diemen's Land (Tasmania), where he served a troubled term as LieutenantGovernor of the penal colony until his ignominious recall in 1843. During Franklin's tenure, Jane's zeal for travel and social reform blossomed: she became the first woman to climb Mount Wellington and the first woman to travel overland from Melbourne to Sydney. She established an agricultural settlement on the Huon River to encourage free immigration, and she sought to improve the lot of female convicts.
After Van Diemen's Land, Franklin welcomed the prospect of a renewed search for the Northwest Passage, for success here would restore his somewhat tarnished reputation. After the Erebus and Terror set sail for the Arctic, Lady Franklin busied herself with travel to the West Indies and the United States. And no doubt because it was there, she climbed Mount Washington. By September, 1847, some uneasiness concerning the fate of the Franklin expedition began to be voiced, and in the next two years, the Admiralty sent out several relief expeditions. Lady Franklin contributed to these efforts by offering $£ 3000$ "to any ship finding the lost expedition or making extraordinary exertions in the attempt."

In the years to come, Lady Franklin proved tireless in her support of the search. In April 1849 she encouraged assistance from the President of the United States, pointing out both the $£ 20,000$ reward to ships of any flag that helped the lost party and the opportunity for Americans to wrest from the British the glory of the discovery of the Northwest Passage. The latter point is evidence of Jane Franklin's desperation. She personally visited the Orkneys and Shetlands to interview whaling parties returning from the Arctic; she appealed to the Emperor of Russia for assistance north of Siberia; and, with several of her friends, she privately equipped the Prince Albert, one of many search vessels.

When Dr. Rae reported, in the autumn of 1854 , that Eskimos had told of seeing white men dying on King William Land four years previously, Lady Franklin concentrated her energies on winning for her husband the distinction of having discovered the Northwest Passage, for by this time Robert McClure had returned from the Arctic to claim that honour. But she still wished to determine the circumstances of the disaster and to rescue any survivors. All her hopes were now placed on Leopold McClintock in command of the Fox, a yacht purchased and refitted for work in the ice at Lady Franklin's expense. This seemed her final chance, for the British public was now distracted by the Crimean War. McClintock returned on 20 September 1859 with relics and a single document that told part of the story. For her perseverance, Lady Franklin was awarded the Founder's Gold Medal of the Royal Geographical Society, conferred for the first time upon a woman.

The energy and determination that had thus far sustained Jane Franklin, and won for her husband a triumph even in his death, continued unabated in her later years. She did not retire into a reclusive widowhood but continued to travel extensively, visiting the United States, South America, Hawaii, Japan, China, India, and Africa. She died on 18 July 1875 at the age of 83 .

Geraldine Rahmani

1212 Bel-Aire Drive S.W. Calgary, Alberta, Canada T2V 2C2 


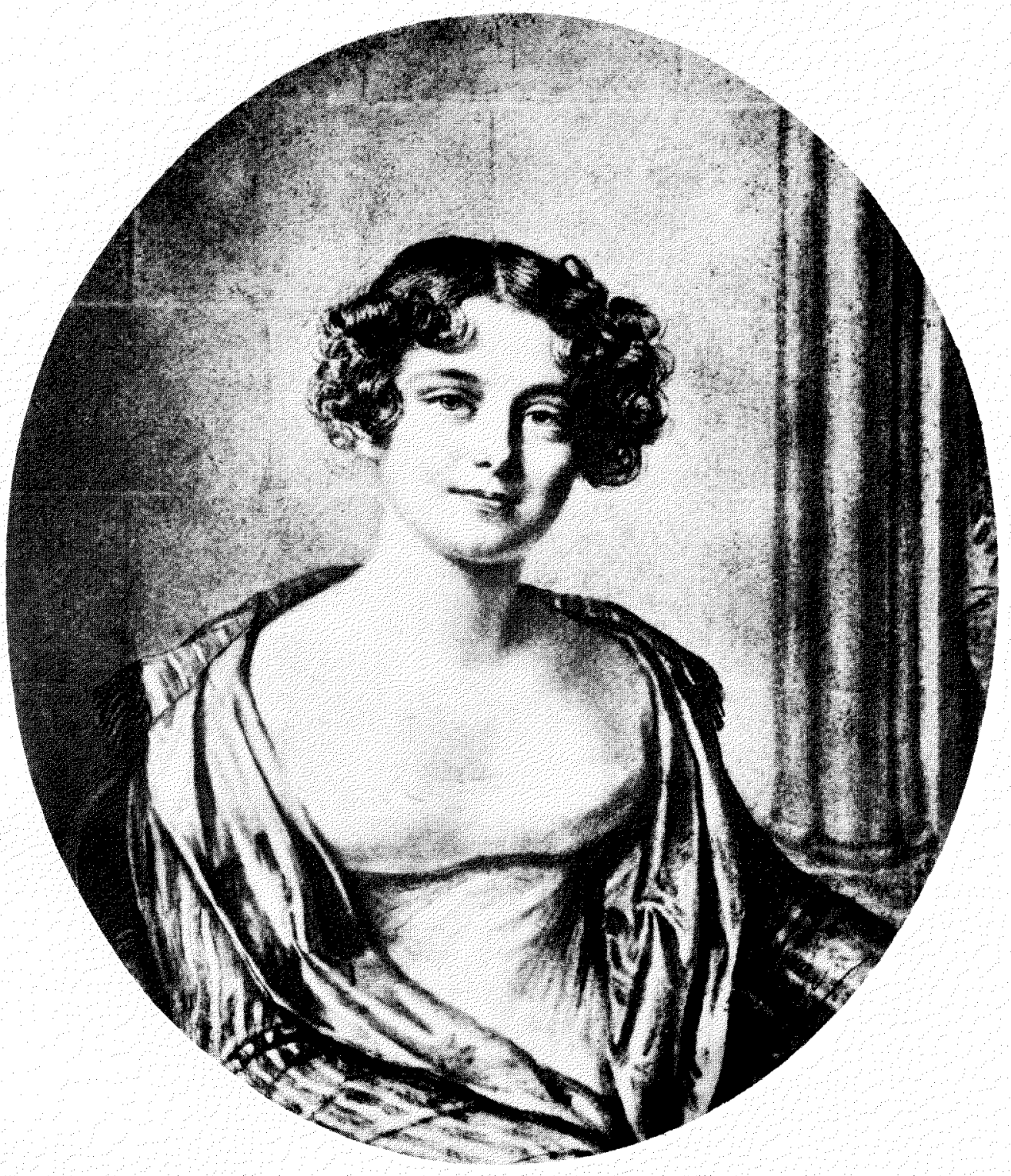

FURTHER READINGS

FITZPATRICK, KATHLEEN. 1949. Sir John Franklin in Tasmania, 1837-1843. Melbourne: Melbourne University Press.

KORN, ALFONS L. 1958. The Victorian Visitors: An Account of the Hawaiian Kingdom, 1861-1866. Honolulu: The University of Hawaii Press.

SMITH, DOROTHY BLAKEY. (ed.). 1974. Lady Franklin Visits the Pacific Northwest. Victoria: Provincial Archives of British Columbia.

WOODWARD, FRANCES J. 1951. Portrait of Jane: A Life of Lady Franklin. London: Hodder and Stoughton. 